\title{
Antibacterial and antioxidant properties of the methanol extracts of the leaves and stems of Calpurnia aurea
}

\author{
Adeolu A Adedapo*+1, Florence O Jimoh², Srinivas Koduru², \\ Anthony J Afolayan ${ }^{2}$ and Patrick J Masika ${ }^{3}$
}

\begin{abstract}
Address: ${ }^{1}$ Department of Veterinary Physiology, Biochemistry and Pharmacology, University of Ibadan, Ibadan, Nigeria, ${ }^{2}$ Department of Botany, University of Fort Hare, Alice 5700, South Africa and ${ }^{3}$ ARDRI, University of Fort Hare, Alice 5700, South Africa

Email: Adeolu A Adedapo* - adedapo3a@yahoo.co.uk; Florence O Jimoh - asjimoh02@yahoo.com;

Srinivas Koduru - sreenivasvedicu@gmail.com; Anthony J Afolayan - aafolayan@ufh.ac.za; Patrick J Masika - pmasika@ufh.ac.za

* Corresponding author †Equal contributors
\end{abstract}

Published: 20 September 2008

BMC Complementary and Alternative Medicine 2008, 8:53 doi:10.1 I86/1472-6882-8-53

This article is available from: http://www.biomedcentral.com/l472-6882/8/53

(C) 2008 Adedapo et al; licensee BioMed Central Ltd.

This is an Open Access article distributed under the terms of the Creative Commons Attribution License (http://creativecommons.org/licenses/by/2.0), which permits unrestricted use, distribution, and reproduction in any medium, provided the original work is properly cited.
Received: 6 June 2008

Accepted: 20 September 2008

\begin{abstract}
Background: In South Africa, Calpurnia aurea (Ait.) Benth is used to destroy lice and to relieve itches, to destroy maggots and to treat allergic rashes, particularly those caused by caterpillars. Antioxidants play an important role protecting against damage by reactive oxygen species. Plants containing flavonoids have been reported to possess strong antioxidant properties.
\end{abstract}

Methods: The antibacterial, antioxidant activities and phenolic contents of the methanol extracts of the leaves and stems of Calpurnia aurea were evaluated using in vitro standard methods. Spectrophotometry was the basis for the determinations of total phenol, total flavonoids, flavonols, and proanthocyanidins. Tannins, quercetin and catechin equivalents were used for these parameters. The antioxidant activities of the stem extract of Calpurnia aurea were determined by ABTS, DPPH, and ferrous reducing antioxidant property (FRAP) methods. Laboratory isolates of 10 bacteria species which included five Gram-positive and five Gram-negative strains were used to assay for antibacterial activity of this plant.

Results: The results from this study showed that the antioxidant activities of the stem extract of Calpurnia aurea as determined by the total phenol, flavonoids, and FRAP methods were higher than that of the leaves. On the other hand, the leaf extract of the plant has higher level of total flavonols and proanthocyanidins. The leaf extract also has higher radical scavenging activity as shown in I, IDiphenyl-2-picrylhydrazyl (DPPH), and 2,2i-azinobis-3- ethylbenzothiazoline-6-sulfonic acid (ABTS) assay. The leaf extract showed activity against seven of the bacterial organisms.

Conclusion: The results from this study indicate that the leaves and stem extracts of Calpurnia aurea possess antioxidant properties and could serve as free radical inhibitors or scavenger or, acting possibly as primary antioxidants. Although, the antibacterial properties of Calpurnia aurea are not as effective as the standard drugs- Chloramphenicol and Streptomycin, they still possess some activity against bacterial strains used in this study. Calpurnia aurea may therefore be a good candidate for functional foods as well as pharmaceutical plant-based products. 


\section{Background}

The genus Calpurnia (Leguminosae) comprises some seven species which are widely distributed in South Africa. Calpurnia aurea (Ait.) Benth. is a yellow-flowered small tree or shrub (Natal Laburnum) widely distributed in Africa from Cape Province to Eritrea and which also occurs in Southern India [1].

Chemical investigations of $C$. aurea have resulted in the isolation of a series of quinolizidine alkaloids. The leaves and twigs of Ethiopian C. aurea yielded 13-hydroxylupanine. The South African species yielded the well known alkaloids: hydroxylupanine, calpurnine, virgiline and its pyrrolylcarboxylic acid ester as found in Ethiopian sample. In addition, the alkaloid 10, 13-dihydroxylupanine was found in $\mathrm{CH}_{2} \mathrm{Cl}_{2}$ extract of the pods. This compound having a MW of 280 and also occurring in Cadia purpurea was absent from the Ethiopian species. Two alkaloids (calpurmenine and 13-2'-pyrrolylcarboxyl) calpurmenine), specifically present in the South African material were isolated from the extracts of leaves and pods [1-3].

Calpurnia aurea is used for the treatment of amoebic dysentery and diarrhea in animals, killing head lice in humans and ticks in animals, syphilis, diarrhea, leishmaniasis, tapeworm, trachoma, Tinea capitis, wound, scabies, elephantiasis and different swellings [4-7]. In South Africa, Calpurnia leaves and powdered roots are used to destroy lice and to relieve itches. Unspecified parts are used to destroy maggots and the leaves are used to treat allergic rashes, particularly those caused by caterpillars. In East Africa, leaf sap is used to destroy maggots in wounds. In Nigeria, the seeds are used to treat abscesses. In Ethiopia it is used to treat stomach complaints, headache, eye diseases, amoebic dysentery, scabies (skin infection caused by ticks) and as an insecticide $[7,8]$.

Free radicals have been implicated in the causation of several diseases such as liver chirrhosis, atherosclerosis, cancer, diabetes, etc. and compounds that can scavenge free radicals have great potential in ameliorating these disease processes [9-14]. Antioxidants thus play an important role to protect the human body against damage by reactive oxygen species $[15,16]$. Free radicals or reactive oxygen species (ROS) are produced in vivo from various biochemical reactions and also from the respiratory chain as a result of occasional leakage. These free radicals are the main culprits in lipid peroxidation [17]. Plants containing flavonoids have been reported to possess strong antioxidant properties $[18,19]$.

Natural products from microorganisms have been the primary source of antibiotics, but with the increasing acceptance of herbal medicine as an alternative form of health care, the screening of medicinal plants for active com- pounds has become very important because these may serve as promising sources of novel antibiotic prototypes [20-22]. It has been shown that in vitro screening methods could provide the needed preliminary observations necessary to select crude plant extracts with potentially useful properties for further chemical and pharmacological investigations [23].

In the present study, the methanol extracts of the leaves and stem of Calpurnia aurea were screened for antioxidant and antibacterial properties using standard methods. The findings from this work may add to the overall value of the medicinal potential of the herb.

\section{Methods \\ Plant collection}

The stems and leaves of Calpurnia aurea were collected July 2006 in the Eastern Cape Province of South Africa. The area falls within the latitudes $30^{\circ} 00-34^{\circ} 15^{\prime} \mathrm{S}$ and longitudes $22^{\circ} 45^{\prime}-30^{\circ} 15^{\prime} \mathrm{E}$. It is bounded by the sea in the east and the drier Karoo (semi-desert vegetation) in the west [24]. These areas consist of villages which are generally classified as rural and poor. The plants were identified by their vernacular names and later validated at the Department of Botany, University of Fort Hare by Professor Grierson and voucher specimens (Aded Med 2007/110) were deposited in the Griffen Herbarium of the University.

\section{Extract preparation}

Both stems and leaves were air dried at room temperature to constant weights. The dried plant materials were separately ground to powders. Two hundred grams of powdered leaves and stem were soaked in $1 \mathrm{~L}$ of methanol separately for 48 hrs on an orbital shaker. Extracts were filtered using a Buckner funnel and Whatman No 1 filter paper. Each filtrate was concentrated to dryness under reduced pressure at $40^{\circ} \mathrm{C}$ using a rotary evaporator. The percentage yield for the leaves was $8.3 \%$ while that of the stems was $7.8 \%$. Each extract was resuspended in methanol to make a $50 \mathrm{mg} / \mathrm{ml}$ stock solution [25].

\section{Chemicals}

1,1-Diphenyl-2-picrylhydrazyl (DPPH), 2,2'-azinobis-3ethylbenzothiazoline-6-sulfonic acid (ABTS), 3-(2-pyridyl)-5,6-diphenyl-1,2,4-triazine-4',4"-disulfonic acid, potassium ferricyanide; catechin, butylated hydroxytoluene (BHT), ascorbic acid, catechin, tannic acid, quercetin and $\mathrm{FeCl}_{3}$ were purchased from Sigma Chemical Co. (St. Louis, MO, USA)., vanillin from BDH; Folin-Ciocalteus's phenol reagent and sodium carbonate were from Merck Chemical Supplies (Damstadt, Germany). All the other chemicals used including the solvents, were of analytical grade. 


\section{Determination of total phenolics}

Total phenol contents in the extracts were determined by the modified Folin-Ciocalteu method [26]. An aliquot of the extract was mixed with $5 \mathrm{ml}$ Folin-Ciocalteu reagent (previously diluted with water 1:10 v/v) and $4 \mathrm{ml}(75 \mathrm{~g} / \mathrm{l}$ ) of sodium carbonate. The tubes were vortexed for $15 \mathrm{sec}$ and allowed to stand for $30 \mathrm{~min}$ at $40^{\circ} \mathrm{C}$ for color development. Absorbance was then measured at $765 \mathrm{~nm}$ using the Hewlett Packard UV-VS spectrophotometer. Samples of extract were evaluated at a final concentration of 0.1 $\mathrm{mg} / \mathrm{ml}$. Total phenolic content were expressed as $\mathrm{mg} / \mathrm{g}$ tannic acid equivalent using the following equation based on the calibration curve: $y=0.1216 x, R^{2}=0.9365$, where $\mathrm{x}$ was the absorbance and $\mathrm{y}$ was the tannic acid equivalent $(\mathrm{mg} / \mathrm{g})$.

\section{Determination of total Flavonoids}

Total flavonoids were estimated using the method of Ordon ez et al. [27]. To $0.5 \mathrm{ml}$ of sample, $0.5 \mathrm{ml}$ of $2 \%$ $\mathrm{AlCl}_{3}$ ethanol solution was added. After one hour at room temperature, the absorbance was measured at $420 \mathrm{~nm}$. A yellow color indicated the presence of flavonoids. Extract samples were evaluated at a final concentration of $0.1 \mathrm{mg} /$ $\mathrm{ml}$. Total flavonoid content were calculated as quercetin $(\mathrm{mg} / \mathrm{g})$ using the following equation based on the calibration curve: $\mathrm{y}=0.0255 \mathrm{x}, \mathrm{R}^{2}=0.9812$, where $\mathrm{x}$ was the absorbance and was the quercetin equivalent $(\mathrm{mg} / \mathrm{g})$.

\section{Determination of total Flavonols}

Total flavonols in the plant extracts were estimated using the method of Kumaran and Karunakaran [28]. To $2.0 \mathrm{~mL}$ of sample (standard), $2.0 \mathrm{~mL}$ of $2 \% \mathrm{AlCl}_{3}$ ethanol and 3.0 $\mathrm{mL}(50 \mathrm{~g} / \mathrm{L})$ sodium acetate solutions were added. The absorption at $440 \mathrm{~nm}$ was read after $2.5 \mathrm{~h}$ at $20^{\circ} \mathrm{C}$. Extract samples were evaluated at a final concentration of $0.1 \mathrm{mg} /$ $\mathrm{ml}$. Total flavonoid content was calculated as quercetin $(\mathrm{mg} / \mathrm{g})$ using the following equation based on the calibration curve: $\mathrm{y}=0.0255 \mathrm{x}, \mathrm{R}^{2}=0.9812$, where $\mathrm{x}$ was the absorbance and was the quercetin equivalent $(\mathrm{mg} / \mathrm{g})$.

\section{Determination of total proanthocyanidins}

Determination of proanthocyanidin was based on the procedure reported by Sun et al. [29]. A volume of $0.5 \mathrm{ml}$ of $0.1 \mathrm{mg} / \mathrm{ml}$ of extract solution was mixed with $3 \mathrm{ml}$ of $4 \%$ vanillin-methanol solution and $1.5 \mathrm{ml}$ hydrochloric acid; the mixture was allowed to stand for $15 \mathrm{~min}$. The absorbance was measured at $500 \mathrm{~nm}$. Extract samples were evaluated at a final concentration of $0.1 \mathrm{mg} / \mathrm{ml}$. Total proanthocyanidin content were expressed as catechin equivalents $(\mathrm{mg} / \mathrm{g})$ using the following equation based on the calibration curve: $\mathrm{y}=0.5825 \mathrm{x}, \mathrm{R}^{2}=0.9277$, where $\mathrm{x}$ was the absorbance and $\mathrm{y}$ is the catechin equivalent $(\mathrm{mg} / \mathrm{g})$.

\section{Determination of antioxidant activity \\ $A B T S$ radical scavenging assay}

For ABTS assay, the method of Re et al. [30] was adopted. The stock solutions included $7 \mathrm{mM}$ ABTS solution and 2.4 $\mathrm{mM}$ potassium persulfate solution. The working solution was then prepared by mixing the two stock solutions in equal quantities and allowing them to react for $12 \mathrm{~h}$ at room temperature in the dark. The solution was then diluted by mixing $1 \mathrm{ml}$ ABTS.+ solution with $60 \mathrm{ml}$ methanol to obtain an absorbance of $0.706 \pm 0.001$ units at $734 \mathrm{~nm}$ using the spectrophotometer. Fresh ABTS solution was prepared for each assay. Plant extracts $(1 \mathrm{ml})$ were allowed to react with $1 \mathrm{ml}$ of the ABTS solution and the absorbance was taken at $734 \mathrm{~nm}$ after 7 min using the spectrophotometer. The ABTS ${ }^{+}$scavenging capacity of the extract was compared with that of BHT and percentage inhibition calculated as ABTS radical scavenging activity $\left.(\%)=\left[\left(\mathrm{Abs}_{\text {control }}-\mathrm{Abs}_{\text {sample }}\right)\right] /\left(\mathrm{Abs}_{\text {control }}\right)\right] \times 100$ where $\mathrm{Abs}_{\text {control }}$ is the absorbance of ABTS radical + methanol; $\mathrm{Abs}_{\text {sample }}$ is the absorbance of ABTS radical + sample extract/standard.

\section{DPPH radical scavenging assay}

The effect of extracts on DPPH radical was estimated using the method of Liyana-Pathirana and Shahidi [31]. A solution of $0.135 \mathrm{mM}$ DPPH in methanol was prepared and $1.0 \mathrm{ml}$ of this solution was mixed with $1.0 \mathrm{ml}$ of extract in methanol containing $0.02-0.1 \mathrm{mg}$ of the extract. The reaction mixture was vortexed thoroughly and left in the dark at room temperature for $30 \mathrm{~min}$. The absorbance of the mixture was measured spectrophotometrically at $517 \mathrm{~nm}$. Ascorbic acid and BHT were used as references. The ability to scavenge DPPH radical was calculated by the following equation: DPPH radical scavenging activity (\%) = $\left[\left(\mathrm{Abs}_{\text {control }}-\mathrm{Abs}_{\text {sample }}\right)\right] /\left(\mathrm{Abs}_{\text {control })}\right] \times 100$ where $\mathrm{Abs}_{\text {control }}$ is the absorbance of DPPH radical + methanol; Abs sample is the absorbance of DPPH radical + sample extract/standard.

Total antioxidant activity (FRAP assay)

A modified method of Benzie and Strain [32] was adopted for the FRAP assay. The stock solutions included $300 \mathrm{mM}$ acetate buffer $\left(3.1 \mathrm{~g} \mathrm{C}_{2} \mathrm{H}_{3} \mathrm{NaO}_{2} \cdot 3 \mathrm{H}_{2} \mathrm{O}\right.$ and $16 \mathrm{ml}$ $\left.\mathrm{C}_{2} \mathrm{H}_{4} \mathrm{O}_{2}\right), \mathrm{pH} 3.6,10 \mathrm{mM}$ TPTZ $(2,4$, 6-tripyridyl-s-triazine) solution in $40 \mathrm{mM} \mathrm{HCl}$, and $20 \mathrm{mM} \mathrm{FeCl}_{3} \cdot 6 \mathrm{H}_{2} \mathrm{O}$ solution. The fresh working solution was prepared by mixing $25 \mathrm{ml}$ acetate buffer, $2.5 \mathrm{ml} \mathrm{TPTZ}$, and $2.5 \mathrm{ml}$ $\mathrm{FeCl}_{3} \cdot 6 \mathrm{H}_{2} \mathrm{O}$. The temperature of the solution was raised to $37^{\circ} \mathrm{C}$ before using. Plant extracts $(150 \mu \mathrm{L})$ were allowed to react with $2850 \mu$ l of the FRAP solution for 30 min in the dark condition. Readings of the colored product (ferrous tripyridyltriazine complex) were taken at 593 $\mathrm{nm}$. The standard curve was linear between 200 and 1000 $\mu \mathrm{M} \mathrm{FeSO}_{4}$. Results were expressed in $\mu \mathrm{M} \mathrm{Fe}$ (II)/g dry mass 
and compared with that of BHT, ascorbic acid and catechin.

\section{Bioassay}

Laboratory isolates of 10 bacteria species which included five Gram-positive and five Gram-negative strains were obtained from the Department of Biochemistry and Microbiology, Rhodes University, South Africa. The Gram-positive strains were Bacillus cereus, Staphylococcus epidermidis, Staphylococcus aureus, Micrococcus kristinae, and Streptococcus pyogens). The five Gram- negative strains were Escherichia coli, Salmonella pooni, Serratia marcescens, Pseudomonas aeruginosa, and Klebsiella pneumoniae. Each organism was maintained on nutrient agar slants and was recovered by sub-culturing in nutrient broth (Biolab No. 2) for $24 \mathrm{hrs}$. Before use, each bacterial culture was diluted 1:100 with fresh sterile nutrient broth [33].

Test organisms were streaked in a radial pattern on sterile nutrient agar plates and incubated at $37^{\circ} \mathrm{C}$ and examined after 24 and 48 hrs. Complete suppression of growth by a specific concentration of an extract was required to be declared active. Each extract was tested at final concentrations of $0.1,0.5,1.0,2.5$ and $5.0 \mathrm{mg} / \mathrm{ml}[22,34]$. Blank plates containing only nutrient agar, and other sets containing nutrient agar and methanol served as controls while Chloramphenicol and Streptomycin served as standards. Each treatment was performed in triplicate and complete inhibition of bacterial growth was required for an extract to be declared bioactive.

\section{Statistical analysis}

The experimental results were expressed as mean \pm standard error of mean (SEM) of three replicates. Where applicable, the data were subjected to one way analysis of variance (ANOVA) and differences between samples were determined by Duncan's Multiple Range test using the Statistical Analysis System (SAS, 1999) program. $P$ values $<0.05$ were regarded as significant and $P$ values $<0.01$ as very significant.

\section{Results}

Total phenolic, flavonoids and proanthocyanidin contents Results obtained in the present study revealed that the level of these phenolic compounds in the methanol extracts of the leaves and stem of C. aurea were considerable. The stem extract higher levels of total phenol and flavonoids than the leaf extract. On the other hand, the leaf extract possessed higher levels of proanthocyanidins and total flavonols (Table 1).

\section{Total antioxidant power (FRAP)}

The reducing ability of the extracts was in the range of 111.49 - $3146.89 \mu \mathrm{m} \mathrm{Fe}$ (II)/g (Table 2). The FRAP values for the extracts were significantly lower than that of ascor-
Table I: Polyphenol contents of the methanol extracts of the leaves and stems of Calpurnia aurea. $(n=3, X \pm S E M)$.

\begin{tabular}{lll}
\hline Phenolics & Leaves & Stems \\
\hline Total polyphenola $^{\mathrm{a}}$ & $9.62 \pm 0.53$ & $11.79 \pm 0.14^{*}$ \\
Flavonoids $^{\mathrm{b}}$ & $0.81 \pm 0.02$ & $1.11 \pm 0.02^{*}$ \\
Total Flavonolc $^{\mathrm{c}}$ & $0.83 \pm 0.10^{*}$ & $0.10 \pm 0.02$ \\
Proanthocyanidins $^{\mathrm{d}}$ & $4.37 \pm 0.32^{*}$ & $1.10 \pm 0.04$ \\
\hline
\end{tabular}

aExpressed as mg tannic acid/g of dry plant material.

bExpressed as $\mathrm{mg}$ quercetin/g of dry plant material.

cExpressed as $\mathrm{mg}$ quercetin/g of dry plant material.

dExpressed as $\mathrm{mg}$ quercetin/g of dry plant material

* indicates that this value is significantly different from the other at $\mathrm{P}<$ 0.05

bic acid, quercetin and catechin, but higher than that of BHT.

\section{DPPH radical scavenging activity}

Figure 1 shows the dose-response curve of DPPH radical scavenging activity of the methanolic extracts of the leaves and stem of $C$. aurea, compared with BHT and ascorbic acid. It was observed that extract of the leaves had higher activity than that of the stem. At a concentration of 0.1 $\mathrm{mg} / \mathrm{ml}$, the scavenging activity of the leaves reached $89.7 \%$, while at the same concentration, that of the stem was $67.0 \%$.

\section{ABTS radical scavenging activity}

The methanol extracts of the leaves and stem of $C$. aurea were fast and effective scavengers of the ABTS radical (Fig 2 ) and this activity was comparable to that of BHT. The percentage inhibition was $100,98.8$ and $99.3 \%$ for the leaf, stem and BHT respectively.

\section{Antibacterial activity}

The antibacterial activity of the extracts of the leaves and stem of the plant is presented in Table 3. The antibacterial activity of the methanol extracts of the leaves of the $C$. aurea is much higher than of the stem. The leaf extract also has activity against all the organisms except Serratia marcescens, Pseudomonas aeruginosa and Klebsiella pneumoniae at MIC of $5 \mathrm{mg} / \mathrm{ml}$ while that of the stem was only active against Bacillus cereus and Streptococcus pyrogens at similar concentrations.

Table 2: Total antioxidant activity of the leaves and stem extracts of Calpurnia aurea

\begin{tabular}{ll}
\hline Extracts & FRAP \\
\hline Leaves & $111.98 \pm 38.89$ \\
Stem & $3146.98 \pm 63.67$ \\
Ascorbic acid & $1632.1 \pm 16.95$ \\
BHT & $63.46 \pm 2.49$ \\
Catechin & $972.02 \pm 0.61$ \\
Quercetin & $3107.29 \pm 31.28$ \\
\hline
\end{tabular}


DPPH scavenging activities of the methanolic extracts of the leaves and stem of Calpurnia aurea

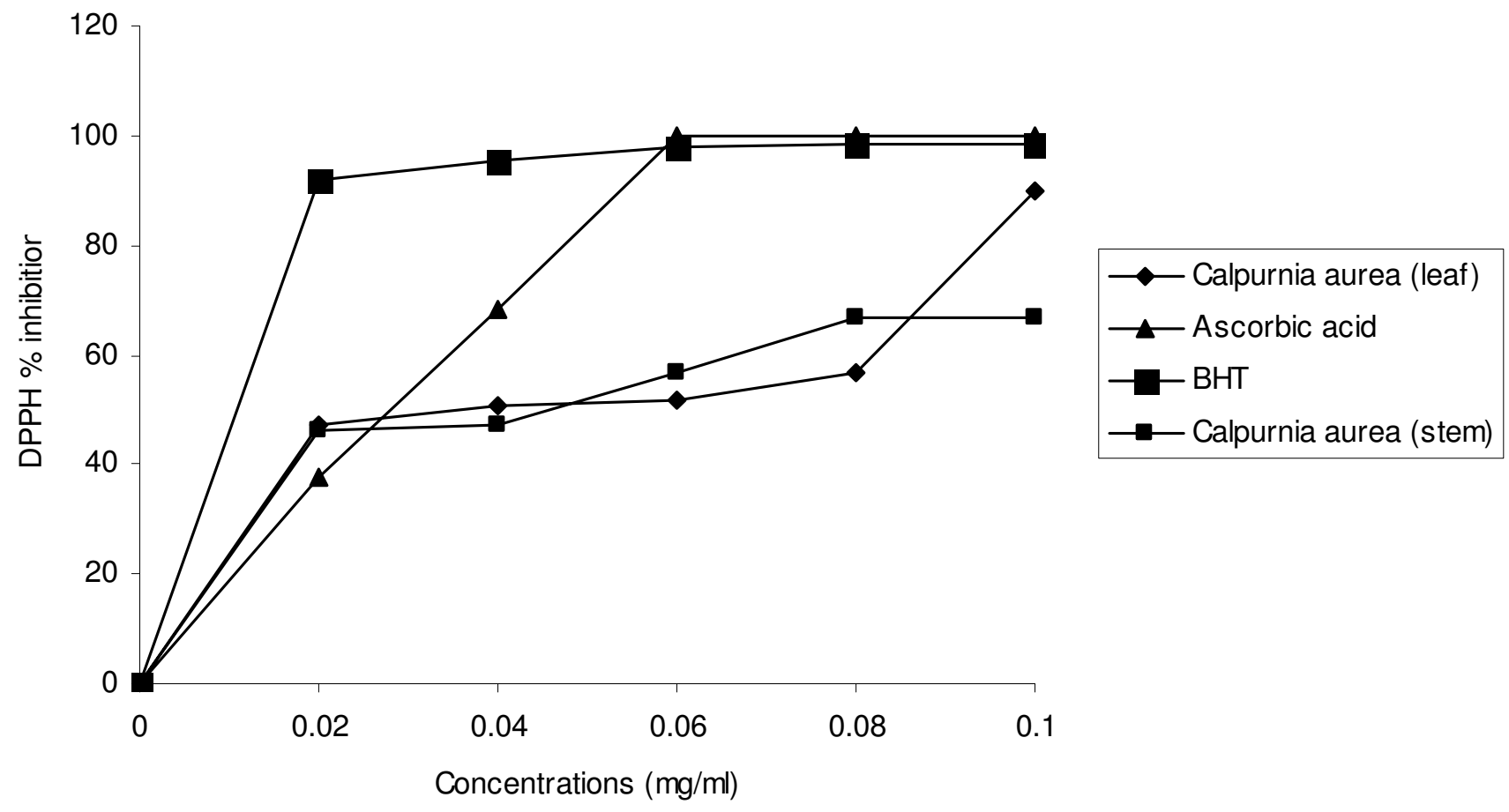

Figure I

\section{Discussion}

Total phenolic, flavonoids and proanthocyanidin contents Polyphenols are the major plant compounds with antioxidant activity. This activity is believed to be mainly due to their redox properties [35], which play an important role in adsorbing and neutralizing free radicals, quenching singlet and triplet oxygen, or decomposing peroxides. Results obtained in the present study revealed that the level of these phenolic compounds in the methanol extracts of the leaves and stem of $C$. aurea were considerable (Table 1). The results strongly suggest that phenolics are important components of this plant, and some of its pharmacological effects could be attributed to the presence of these valuable constituents.

\section{Total antioxidant power (FRAP)}

The antioxidant potentials of the methanol extracts of the leaves and stem of $C$. aurea were estimated from their ability to reduce TPRZ-Fe (III) complex to TPTZ-Fe (II). The reducing ability of the extracts was in the range of 111.49 - $3146.89 \mu \mathrm{m} \mathrm{Fe}$ (II)/g (Table 2). Antioxidant activity increased proportionally with the polyphenol content.
According to recent reports, a highly positive relationship between total phenols and antioxidant activity appears to be the trend in many plant species [36].

\section{DPPH radical scavenging activity}

The effect of antioxidants on DPPH is thought to be due to their hydrogen donating ability [38]. Though the DPPH radical scavenging abilities of the extracts were significantly less than those of ascorbic acid (100\%) and BHT (98.3), the study showed that the extracts have the proton-donating ability and could serve as free radical inhibitors or scavengers, acting possibly as primary antioxidants.

\section{ABTS radical scavenging activity}

Proton radical scavenging is an important attribute of antioxidants. ABTS, a protonated radical, has characteristic absorbance maxima at $734 \mathrm{~nm}$ which decreases with the scavenging of the proton radicals [37]. The methanol extracts of the leaves and stem of $C$. aurea were fast and effective scavengers of the ABTS radical (Fig 2) and this activity was comparable to that of BHT. Higher concentra- 


\section{ABTS activities of the methanolic extracts of the stem and leaves of Calpurnia aurea}

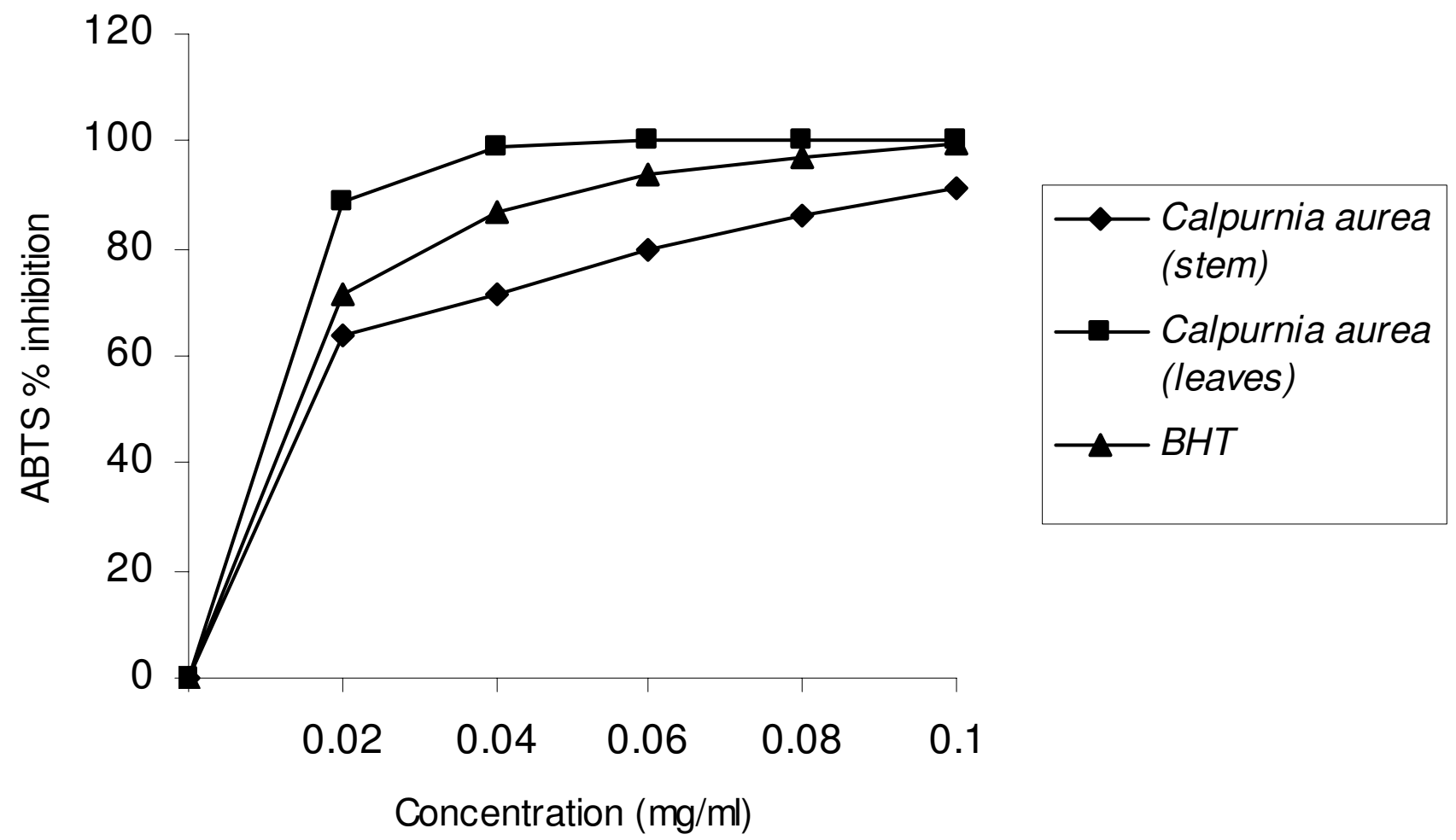

Figure 2

ABTS scavenging activities of the methanolic extracts of the leaves and stem of Calpurnia aurea.

tions of the extracts were more effective in quenching free radicals in the system.

The scavenging of the ABTS radical by the extracts was found to be much higher than that of DPPH radical. Factors like stereoselectivity of the radicals or the solubility of the extract in different testing systems have been reported to affect the capacity of extracts to react and quench different radicals [39]. Wang et al. [40] found that some compounds which have ABTS scavenging activity did not show DPPH scavenging activity. In this study, the extracts showed strong scavenging activities against DPPH and ABTS radicals. This further showed the capability of the extracts to scavenge different free radicals in different systems, indicating that they may be useful therapeutic agents for treating radical-related pathological damage.

\section{Antibacterial activity}

The antibacterial activity of the methanol extracts of the leaves of the C. aurea is much higher than of the stem. It was observed that Calpurnia aurea showed strong antibacterial activity comparable to that of standard gentamycin $(0.1 \mathrm{mg} / \mathrm{ml})$ though at MIC of $100 \mathrm{mg} / \mathrm{ml}$ [7]. Though the minimum inhibitory concentration of $5 \mathrm{mg} / \mathrm{ml}$ is very high, nevertheless it showed that the plant extracts under in vitro study has broad spectrum antibacterial activity. It is known that, in general, the Gram-negative bacteria are more resistant than the Gram-positive ones [41,42], however, the study showed that 2 of the Gram-negative organisms used in this study were sensitive to this extract even then at high MIC of $5 \mathrm{mg} / \mathrm{ml}$. Streptococcus pyogens is a known pathogen of respiratory infections [43]; its inhibition by the two extracts might suggest their possible use in 
Table 3: Antibacterial activity of the leaves and stem extracts of Calpurnia aurea.

\begin{tabular}{|c|c|c|c|c|c|}
\hline \multirow[b]{2}{*}{ Bacterial species } & \multirow[b]{2}{*}{ Gram +/- } & \multicolumn{3}{|c|}{ Minimum inhibitory concentration (mg/ml) } & \multirow[b]{2}{*}{ Streptomycin $\mu g / m l$} \\
\hline & & Leaves & Stem & Chloramphenicol $\mu \mathrm{g} / \mathrm{ml}$ & \\
\hline Bacillus cereus & + & 5.0 & 5.0 & $<2$ & $<2$ \\
\hline Staphylococcus epidermidis & + & 5.0 & na & $<2$ & $<2$ \\
\hline Staphylococcus aureus & + & 5.0 & na & $<2$ & $<2$ \\
\hline Micrococcus kristinae & + & 5.0 & na & $<2$ & $<2$ \\
\hline Streptococcus pyogens & + & 5.0 & 5.0 & $<2$ & $<2$ \\
\hline Escherichia coli & - & 5.0 & na & $<2$ & $<2$ \\
\hline Salmonella pooni & - & 5.0 & na & $<2$ & $<2$ \\
\hline Serratia marcescens & - & na & na & $<2$ & $<2$ \\
\hline Pseudomonas aeruginosa & - & na & na & $<20$ & $<5$ \\
\hline Klebsiella pneumonae & - & na & na & $<2$ & $<2$ \\
\hline
\end{tabular}

na $=$ not active.

the treatment of chest and respiratory infections. Furthermore, Escherichia coli, which is a Gram-negative bacterium, was also inhibited by the leave extract. Although it belongs to the normal flora of humans, an enterohaemorrhagic strain of $E$. coli has caused serious food poisoning, and preservatives to eliminate its growth are needed $[44,45]$; the extracts of $C$. aurea might therefore be of use.

\section{Conclusion}

The results from this study indicate that the leaves and stem extracts of Calpurnia aurea possess antioxidant properties and could serve as free radical inhibitors or scavenger or, acting possibly as primary antioxidants. The antibacterial properties of Calpurnia aurea are not as effective as the standard drugs- Chloramphenicol and Streptomycin, but microorganisms become resistant to antibiotics over time. Again, of recent, a lot of attention is being devoted to natural sources of antioxidant and antibacterial materials, the data obtained in this study might suggest a possible use of Calpurnia aurea as a source of natural antioxidant and antimicrobial agents.

\section{Competing interests}

The authors declare that they have no competing interests.

\section{Authors' contributions}

AAA: Prepare the extract, carried out the assays and drafted the manuscript.

FOJ: Carried out the assay

SK: Carried out the bioassay

\section{AJA: Coordinated the study}

PJM: Provided the grants for the study and also coordinated the study.
All authors read and approved the final manuscript.

\section{Acknowledgements}

The authors wish to acknowledge the financial support of Govan Mbeki Research and Development Center (GMRDC) of the University of Fort Hare for funding the research.

\section{References}

I. Asres K, Gibbons W, Phillipson JD, Mascgani P: Alkaloids of Ethiopian. Calpurnia aurea Phytochem 1986, 25: I 443-I 447.

2. Radema MH, Van Eijk JL, Vermint W, De Kok AJ, Romers C: Alkaloids of South African samples of Calpurnia aurea subsp. sylvatica. Phytochem 1979, 1 8:2063-2064.

3. Asres K, David P, Polo M: Two novel minor alkaloids from Ethiopian Calpurnia aurea. Planta Medica 1986, 25:302-304.

4. Asres K: Alkaloids and flavonoids from the species of Leguminosae. In PhD thesis University of London, School of Pharmacy; 1986:49-52.

5. Abebe $D$, Ayehu A: Medicinal plants and enigmatic health practices of Northern Ethiopia. Addis Ababa, Ethiopia 1993.

6. Fullas F: Ethiopian traditional medicine: Common medicinal plants in perspective. US Ist edition. 2001.

7. Tadeg H, Mohammed E, Asres K, Gebre-Mariam T: Antimicrobial activities of some selected traditional Ethiopian medicinal plants used in the treatment of skin disorders. J Ethnopharmacol 2005, 100:168-175.

8. Asres K, Bucar F, Kartnig T, Witvrouw M, Pannecouque C, De Clercq $\mathrm{E}$ : Antiviral activity against human immunodeficiency virus type I (HIV-I) and type 2 (HIV-2) of ethnobotanically selected Ethiopian medicinal plants. Phytother Res 200I, I 5:62-69.

9. Wilson RL: Free radicals and tissue damage, mechanistic evidence from radiation studies. In Biochemical mechanisms of liver injury Academy Press, New York; 1988: 123.

10. Geber M, Boutron-Ruault MC, Hercberg S, Riboli E, Scalbert A, Siess $\mathrm{MH}$ : Food and cancer: state of the art about the protective effect of fruits and vegetables. Bull Cancer 2002, 89:293-312.

II. Kris-Etherton PM, Hecker KD, Bonanome A, Coval SM, Binkosi AE, Hilpert KF: Bioactive compounds in foods: their role in the prevention of cardiovascular disease and cancer. Amer J Med 2002, I I 3:7|S-88S.

12. Serafini M, Bellocco R, Wolk A, Ekstrom AM: Total antioxidant potential of fruit and vegetables and risk of gastric cancer. Gastroenterol 2002, | 23:985-99|.

13. Di Matteo V, Esposito E: Biochemical and therapeutic effects of antioxidants in the treatment of Alzheimer's disease, Parkinson's disease, and amyotrophic lateral sclerosis. Curr Drug target CNS Neurological Disorders 2003, 2:95-107.

14. Behera BC, Verma N, Sonone A, Makhija U: Determination of antioxidative potential of lichen Usnea ghattensis in vitro. LWT 2006, 39:80-85. 
15. Lollinger J: Free radicals and food additives. Taylor and Francis London; 1981:21.

16. Tutour BL: Antioxidative activities of algal extracts. Synergistic effect with vitamin E. Phytochem 1990, 29:3759-3765.

17. Cheeseman $\mathrm{KH}$, Scater TF: Free radical in medicine. In British Medical Bulletin Volume 49. Churchill Livingstone, London; 2003:479-724

18. Raj KJ, Shalini K: Flavonoids-a review of biological activities. Indian Drugs 1999, 36:668-676.

19. Badami S, Gupta MK, Suresh B: Antioxidant activity of the ethanolic extract of Striga orobanchioides. J Ethnopharmacol 2003, 85:227-230.

20. Meurer-Grimes B, Mcbeth DL, Hallihan B, Delph S: Antimicrobial activity in medicinal plants of the Scrophulariaceae and Acanthaceae. Intl J Pharmacog 1996, 34:243-248.

21. Rabe T, Van Staden J: Antibacterial activity of South African plants used for medicinal purposes. J Ethnopharmacol 1997 56:8I-87.

22. Koduru S, Grierson DS, Afolayan AJ: Antimicrobial activity of Solanum aculeastrum. Pharm Biol 2006, 44(4):283-286.

23. Mathekaga ADM, Meyer JJM: Antibacterial activity of South African Helichrysum species. S Afr J Bot 1998, 64:293-295.

24. Masika PJ, Afolayan AJ: An ethnobotanical study of plants used for the treatment of livestock diseases in the Eastern Cape Province, South Africa. Pharm Biol 2003, 41:16-2I.

25. Taylor RSL, Edel F, Manandhar NP, Towers GHN: Antimicrobial activity of southern Nepalese medicinal plants. J Ethnopharmacol 1996, 45:67-70.

26. Wolfe K, Wu X, Liu RH: Antioxidant activity of apple peels. J Agr Food Chem 2003, 5 I:609-6I4.

27. Ordon ez AAL, Gomez JD, Vattuone MA, Isla MI: Antioxidant activities of Sechium edule (Jacq.) Swart extracts. Food Chem 2006, 97:452-458.

28. Kumaran A, Karunakaran RJ: In vitro antioxidant activities of methanol extracts of Phyllanthus species from India. LWT 2007, 40:344-352.

29. Sun JS, Tsuang YW, Chen IJ, Huang WC, Hang YS, Lu FJ: An ultraweak chemiluminescence study on oxidative stress in rabbits following acute thermal injury. Burns 1998, 24:225-231.

30. Re R, Pellegrini N, Proteggente A, Pannala A, Yang M, Rice-Evans C: Antioxidant activity applying an improved ABTS radical cation decolorization assay. Free Radical Bio Med 1999, 26: $|23|-\mid 237$.

31. Liyana-Pathiranan CM, Shahidi F: Antioxidant activity of commercial soft and hard wheat (Triticum aestivum $L$ ) as affected by gastric pH conditions. J Agr Food Chem 2005, 53:2433-2440.

32. Benzie IFF, Strain JJ: The ferric reducing ability of plasma (FRAP) as a measure of "antioxidant power": the FRAP assay. Anal Biochem 1996, 239:70-76.

33. Afolayan AJ, Meyer JIM: The antimicrobial activity of 3,5,7-trihydroxyflavone isolated from the shoot of Helichrysum aureonitens. J Ethnopharmacol 1997, 57:177-181.

34. Meyer JJM, Afolayan AJ: Antibacterial activity of Helichrysum aureonitens (Asteraceae). J Ethnopharmacol 1995, 47: 109-III.

35. Zheng W, Wang SY: Antioxidant activity and phenolic compounds in selected herbs. I Agr Food Chem 200I, 49:5I65-5I70.

36. Oktay M, Gülçin Q, Küfrevio@lu Öl: Determination of in vitro antioxidant activity of fennel (Foeniculum vulgare) seed extracts. Lebens-Wiss Technol 2003, 36:263-27I.

37. Mathew S, Abraham ET: In vitro antioxidant activity and scavenging effects of Cinnamomum verum leaf extract assayed by different methodologies. Food Chem Toxicol 2004, 44:198-206.

38. Baumann J, Wurn G, Bruchlausen FV: Prostaglandin synthetase inhibiting $\mathrm{O}_{2}$, radical scavenging properties of some flavonoids and related phenolic compounds. Deutsche Pharmakologische Gesellschaft Abstracts of the 20th spring meeting, NaunynSchmiedebergs Abstract No: R27 cited in Arch Pharmacol 1979, 307:RI-R77

39. Yu L, Haley S, Perret J, Harris M, Wilson J, Qian M: Free radical scavenging properties of wheat extracts. J Agr Food Chem 2002, 50:1619-1624.

40. Wang M, Li J, Rangarajan M, Shao Y, La Voie EJ, Huang T, Ho C: Antioxidative phenolic compounds from Sage (Salvia officinalis). J Agr Food Chem 1998, 46:4869-4873.
41. Grierson DS, Afolayan A): Antibacterial activity of some indigenous plants used for the treatment of wounds in the Eastern Cape, South Africa. J Ethnopharmacol 1999, 66:103-106.

42. Afolayan AJ: Extracts from the shoots of Arctotis arctotoides inhibit the growth of bacteria and fungi. Pharm Biol 2003, 41:22-25.

43. Rojas G, Levaro J, Tortoriello J, Navarro V: Antimicrobial evaluation of certain plants used in Mexican traditional medicine for the treatment of respiratory diseases. J Ethnopharmacol 2001, 74:97-101.

44. Buchanan RL, Doyle MP: Food borne disease significance of Escherichia coli 0157:H7 and other enterohaemorrhagic E. coli. Food Technol 1997, 5 I (10):69-76.

45. Gulcin I, Oktay M, Kirecci E, Kufrevioglu IO: Screening of antioxidant and antimicrobial activities of anise (Pimpinella anisum L.) extracts. Food Chem 2003, 83:37I-382.

\section{Pre-publication history}

The pre-publication history for this paper can be accessed here:

http://www.biomedcentral.com/1472-6882/8/53/prepub
Publish with BioMed Central and every scientist can read your work free of charge

"BioMed Central will be the most significant development for disseminating the results of biomedical research in our lifetime. "

Sir Paul Nurse, Cancer Research UK

Your research papers will be:

- available free of charge to the entire biomedical community

- peer reviewed and published immediately upon acceptance

- cited in PubMed and archived on PubMed Central

- yours - you keep the copyright
BioMedcentral 